\title{
Relationship of Physical Activities with Nutrition Status in Students at SMK Negeri 1 Percut Sei Tuan Deli Serdang District
}

\author{
Hasnizar $^{1}$, Evawany Aritonang $^{2}$, Etti Sudaryati $^{2}$ \\ ${ }^{1}$ Master Student in Faculty of Public Health, Universitas Sumatera Utara, Medan, Indonesia \\ ${ }^{2}$ Lecturer in Department of Community Nutrition, Universitas Sumatera Utara, Medan, Medan, Indonesia \\ Email: has_nizar@yahoo.com
}

\begin{abstract}
:
Adolescents are age group that is vulnerable to the nutritional problems. Factors that influence nutritional status in adolescents include physical activity. Physical activity including physical exercise which is one of the efforts to stabilize the intake and expenditure of food substances which is a priority source of energy in the body. The purpose of this study was to analyze the relationship of physical activity with nutritional status in students at SMK Negeri 1 Percut Sei Tuan, Deli Serdang District in 2019. The type of research used was quantitative research with cross sectional research design. The results obtained by the relationship of physical activity with the nutritional status of students $p$ value of 0.003 or smaller than 0.05 . The conclusion of the study is that there is a relationship of physical activity with nutritional status in students at SMK Negeri 1 Percut Sei Tuan. Students who are doing physical activity have normal nutritional status because there is a balance between energy intake and expenditure.

Keywords:

physical activity; nutritional status; adolescence
\end{abstract}

\section{Introduction}

Adolescents are an age group that is vulnerable to nutritional problems because, first the acceleration of growth and body development (growth spurt) requires more energy. Second, changes in lifestyle and eating habits that require equalization of energy and nutrient needs. Third, pregnancy, participation in sports addicted to alcohol and drugs increase energy and nutritional needs, besides that not a few teenagers who overeat and eventually become obese. Adolescents also face the challenges of further problems of nutrition at an early age such as diseases caused by low levels of iron deficiency anemia, malnutrition and over nutrition (Arisman, 2010).

World Health Organization (WHO) in 2015 stated that around the world there were around 1.6 billion adolescents aged 15 years overweight and as many as 400 million obese students and it was estimated that more than 700 million adults became obese in the year 2015 . Based on the results of the National Health and Nutrition Examination Survey in 2011 to 2014 in America the percentage of obesity at the age of two to 19 years was 17 percent with a category based on age group, children aged two to five years by 8.9 percent, ages six to eleven years by 17.5 percent and ages 12 to 19 years by 20.5 percent. According to Wulandari, (2020) health as a component that is very meaningful to humans. With a healthy body, humans will be able to carry out their activities productively. Everyone has a desire for a healthy body, therefore to realize a healthy state, there are several things that must be done, including the existence of health services aimed at the community.

The description of the nutritional status of adolescents in Indonesia based on the results of the Basic Health Research (RISKESDAS) in 2013, the incidence of nutritional status of 
adolescents aged 13-15 years in Indonesia according to the Body Mass Index by Age as much as 11.1 percent thin consists of 3.3 percent very thin and 7.8 percent thin. The incidence of obese teenagers by 10.8 percent consists of 8.3 percent fat and 2.5 percent very fat. In general, there are still 17 provinces in Indonesia with a prevalence of very thin children over the national prevalence and 13 provinces with a prevalence of overweight children above the national prevalence. Teenagers aged 16-18 years, the national prevalence of thin children is 9.4 percent which consists of 1.9 percent very thin and 7.5 percent thin. Globally, there are 11 provinces where the incidence of thin teenagers is above the national incidence rate. The incidence of obese adolescents as much as 7.3 percent consists of 5.7 percent fat and 1.6 percent (Ministry of Health Republic of Indonesia, 2013).

Factors that affect nutritional status in adolescents according to Hidayati (2017), including physical activity. Excessive energy intake and not offset by a balanced expenditure (lack of physical activity) will cause an increase in body weight. Lifestyle changes result in changes in students's food intake which refers to high-calorie, fat and cholesterol food intake, and not balanced with physical activity can cause more nutritional problems. Especially in the current era of globalization with the technological sophistication of many household appliances that are completely automated and online food ordering, causing movement and activities to become increasingly limited and life more relaxed.

Physical activity which includes various bodily activities including physical exercise which is one of the efforts to stabilize the intake and expenditure of food which is a priority source of energy in the body. Physical activities require energy and also accelerate the process of forming and decomposing food substances in the body and serves to balance the food substances that come and go into the body (Ministry of Health Republic of Indonesia, 2014).

The results of 1 Percut Sei Tuan Deli Serdang District on 30 students from 106 grade X and XI students the initial survey at SMK Negeri of Network Computer Engineering with details (59 male and 47 female), through measurement of $1 \times 24$ hour food recall and height and weight measurements using scales and microtoice obtained the following data: six thin students with nutritional status, normal nutritional status of 15 students, fat nutritional status of 9 students. The results of interviews about physical activity in the initial survey most students going and going home from school by riding bike and public transportation at school, students take sports lessons once a week for two hours and extracurricular activities on Saturdays such as basketball, scouts, theater. Coming home from school they only do light activities such as studying, watching television and playing mobile phones. Based on the background above, this research will examine factors that are suspected to influence the nutritional status of adolescents, namely "The Relationship of Physical Activity with Nutritional Status in Students at SMK Negeri 1 Percut Sei Tuan, Deli Serdang District."

\section{Research Method}

This type of research is a quantitative study with cross sectional research design. This research is descriptive observational, that is to know the relationship of physical activity with nutritional status in students at SMK Negeri 1 Percut Sei Tuan, Deli Serdang District in 2019.

The population in this study were all students of class X and XI in Department of Computer Engineering at SMK Negeri 1 Percut Sei Tuan, Deli Serdang District as many as 106 students (59 male and 47 female). The sample in this study was taken from the entire population (total sampling) of 106 students. 
Primary data collection was conducted at SMK Negeri 1 Percut Sei Tuan, Deli Serdang District, there were student height data, student weight data, and physical activity data. Secondary data in the form of data on the number of students at SMK Negeri 1 Percut Sei Tuan Deli Serdang District and books, reference materials such as research journals that are considered relevant to the research topic.

Table 1. Measurement Methods (Variables, Methods, Instruments, Results and Measuring Scale)

\begin{tabular}{|c|c|c|c|c|}
\hline Variabel & $\begin{array}{c}\text { Method } \\
\text { Measurement }\end{array}$ & $\begin{array}{c}\text { Instrument } \\
\text { Measurement }\end{array}$ & $\begin{array}{c}\text { Results } \\
\text { Measurement }\end{array}$ & $\begin{array}{c}\text { Scale } \\
\text { Measurement }\end{array}$ \\
\hline \multicolumn{5}{|l|}{ - Independen } \\
\hline Physical Activity & $\begin{array}{l}\text { Form of Physical } \\
\text { Activity }\end{array}$ & Interview & $\begin{array}{l}\text { Light, medium, } \\
\text { heavy }\end{array}$ & Ordinal \\
\hline Energy & Food recall & Interview & Less, good, more & Ordinal \\
\hline Protein & Food recall & Interview & Less, good, more & Ordinal \\
\hline Carbohydrate & Food recall & Interview & Less, good, more & Ordinal \\
\hline \multicolumn{5}{|l|}{ - Dependent } \\
\hline Nutritional status & $\begin{array}{l}\text { Measuring } \\
\text { weight, height } \\
\text { and age }\end{array}$ & $\begin{array}{l}\text { Weight Scales, } \\
\text { Microtoise and RI } \\
\text { Minister of Health Table }\end{array}$ & $\begin{array}{l}\text { Very thin, skinny, } \\
\text { Normal, Fat, } \\
\text { Obesity }\end{array}$ & Ordinal \\
\hline
\end{tabular}

Data Processing Techniques are measurements of the respondent's height and weight using microtoise and stepping scales, physical activity data obtained through a questionnaire as a guide. Furthermore, in order to be analyzed, the raw data obtained is processed by a computer program through editing, coding, cleaning, and processing.

\section{Result and Discussion}

\subsection{Research Results}

\section{a. Univariate Analysis}

Based on table 2, the characteristics of students by age there are most students aged greater than 16 years as many as fifty-seven (53.7\%), based on gender there are mostly male students as many as fifty-nine $(55.7 \%)$, and based on class there are a large part of class XI as many as fifty four students $(43.3 \%)$

Table 2. Characteristics of Students in SMK Negeri 1 Percut Sei Tuan

\begin{tabular}{ccc}
\hline Student Characteristics & $\mathbf{n}$ & $\mathbf{( \% )}$ \\
\hline Aged & & \\
1. $\leq 16$ Years old & 52 & 49,1 \\
2. > 16 Years old & 54 & 50,9 \\
Total & 106 & 100 \\
Gender & & \\
1. Male & 59 & 55,7 \\
2. Female & 47 & 44,3 \\
Total & 106 & 100 \\
Class & & \\
1. Class X & 52 & 56,6 \\
2. Class XI & 54 & 43,4 \\
$\quad$ Total & 106 & 100 \\
\hline
\end{tabular}


Table 3 shows that from 106 vocational students based on nutritional status there were mostly normal nutritional status of forty-two students $(39.6 \%)$.

Table 3. The Distribution of Nutrition Status in Students at SMK Negeri 1 Percut Sei Tuan

\begin{tabular}{lcc}
\hline Nutritional Status & $\mathbf{N}$ & $\mathbf{( \% )}$ \\
\hline Thin & 25 & 23,6 \\
Normal & 42 & 39,6 \\
Fat & 39 & 36,8 \\
\hline Total & 106 & 100,0 \\
\hline
\end{tabular}

The distribution of physical activity can be seen in Table 4 showing that from 106 Vocational School students based on physical activity there were mostly having moderate physical activity as many as forty-four students (41.5\%).

Table 4. Distribution of Physical Activity in Students at SMK Negeri 1 Percut Sei Tuan

\begin{tabular}{lcc}
\hline Activities & $\mathbf{N}$ & $\mathbf{( \% )}$ \\
\hline Light & 43 & 40,6 \\
Medium & 44 & 41,5 \\
Weight & 19 & 17,9 \\
\hline Total & 106 & 100,0 \\
\hline
\end{tabular}

\section{b. Bivariate Analysis}

\section{The Relationship of Physical Activity with Nutrition Status}

The relationship of physical activity with nutritional status is obtained that students who have mild physical activity have fat status as many as twenty-four students (55.8\%), then students with moderate physical activity have normal nutritional status as many as twenty-four students $(54.5 \%)$ and students with strenuous activities had normal nutritional status of eight students $(42.1 \%)$.

Table 5. The Relationship of Physical Activity with Nutritional Status in Students at SMK Negeri 1 Percut Sei Tuan

\begin{tabular}{lccccccccc}
\hline Physical & \multicolumn{4}{c}{ Nutritional Status } & \multicolumn{3}{c}{ Total } & P value \\
\cline { 2 - 10 } Activities & Thin & $\%$ & Normal & $\%$ & Fat & $\%$ & N & $\%$ & \\
\hline Light & 9 & 20,9 & 10 & 23,3 & 24 & 55,8 & 43 & 100 & \\
Medium & 13 & 29,5 & 24 & 54,5 & 7 & 15,9 & 44 & 100 & 0,003 \\
Weight & 3 & 15,8 & 8 & 41,2 & 8 & 42,1 & 19 & 100 & \\
\hline Total & 25 & 23,6 & 42 & 39,6 & 39 & 36,8 & 106 & 100 & \\
\hline
\end{tabular}

\subsection{Discussion}

Chi square statistical test results of the relationship of physical activity in students of SMK Negeri 1 Percut Sei Tuan can be seen in Table 5, it is shows that bivariate analysis using the chi square test that the physical activity $\mathrm{p}$ value of 0.003 is smaller than 0.05 , so it can be concluded that there is a relationship physical activity with the nutritional status in students at SMK Negeri 1 Percut Sei Tuan. Then from the results of the cross tabulation shows that students who have mild physical activity have fat status as many as twenty-four students (55.8\%), then students with moderate physical activity have normal nutritional status as many as twenty-four students (54.5\%) and students with strenuous activity having normal nutritional status as many as eight students (42.1\%). 
This is in line with Karim Research (2017), the results of physical activity tests have an $r$ count on the nutritional status of 0.26 with a significance level of 0.045 less than 0.05 indicating that there is a relationship between physical activity and nutritional status which has an interpretation of the correlation value low. The more fulfilled food intake and physical activity, the better the nutritional status.

This is in line with Khasanah research (2016), it is known that girls who have mild physical activity tend to have overweight and obese nutritional status whereas in adolescent girls who have moderate and severe physical activity none have nutritional status of overweight or obese. Statistical test results know the $\mathrm{p}$ value is smaller than $0.05,0.005$ so there is a relationship between physical activity and nutritional status. Physical activity has a considerable influence on the stability of nutritional status. The more active a person's physical activity is, the more energy is expended. If excess energy intake is not matched by physical activity, adolescents are prone to obesity.

Changing lifestyles also cause changes in food intake that is high in calories, fat and cholesterol which unfortunately if not balanced with physical activity will cause more nutritional problems. Food intake with high calories, fat and cholesterol must be balanced with physical activity in order to balance the nutritional intake. The benefits of physical activity is that it can reduce body fat mass and increase muscle strength can prevent excessive accumulation of fat in the body (Sukmaniah, et al, 2013).

This is in line with Yaumil's research (2017), Kendall's Tau test results show that $\mathrm{p}=$ $0,000(\mathrm{p}<0.05)$, so it can be concluded that there is a relationship between physical activity and nutritional status of school-age children obtained correlation coefficient values obtained 0.516 indicates that the closeness of the relationship of physical activity with the nutritional status of school-age children. The highest percentage of the relationship between physical activity and nutritional status of school-age children is students who have mild physical activity category and more nutritional status as much as $54.6 \%$. These results illustrate that the less activity or energy expended by a person, the more a person has an excess body mass index. Because there is no balance between the energy obtained with the energy expended.

This is also in line with the research of Ermona and Wirjatmadi (2018). The results of statistical tests using the chi square test with $\alpha=0.05$ obtained a $\mathrm{p}$ value of 0.024 , where the $\mathrm{p}$ value is smaller than $\alpha$. This shows that there is a relationship of physical activities with over nutritional status. In this study dominated by the low physical activity by respondents. This is because most of the respondents do physical activities organized by the school once a week, that is during sports lessons. Break time is used by respondents to buy snacks that are available inside and outside the school. In addition they spend time off chatting with fellow friends in class. Outside of school hours, most respondents spent time watching television, playing games or studying. This is because an increase in the prevalence of obesity that occurs in school children is caused by one of them that children are more likely to spend their free time watching television and other activities that do not release energy. This is what causes their physical activity is classified as low so it affects the balance of food intake they consume.

This is in line with research Afrilia and Festilia (2018), the results of statistical tests using chi-square showed a relationship between physical activity and nutritional status $(p=0.021$ $<0.05)$. Where students are more nutritional status, more students in mild activity $(35.0 \%)$. In students whose physical activity is mild, some of these students are obese nutritional status, namely seven students $(11.6 \%)$ because the habit of their activities at school only follows the 
learning process in the classroom and does not follow extracurricular activities at school such as in sports, namely, basketball, futsal and table tennis. Most of the activities at home are 31 students $(51.7 \%)$ of these students who spend more time watching TV and playing games.

Physical activity is the body's movements produced by skeletal muscles produced as an energy expenditure (expressed in kilo-calories), which includes work, leisure and daily activities. These activities require mild, moderate or severe effort that can lead to health improvements if done regularly (Duma, 2013).

Physical activity should be done regularly three or more times a week with moderate to heavy exercise levels performed at least 30 minutes every day. Therefore, excessive energy intake without balanced physical activity will make adolescents easily overweight, because changes in body fat mass can be prevented by physical activity (Brown et al. 2013).

In this study it was found that respondents who were physically active had normal nutritional status of 54.5 percent. This is because students of SMK Negeri 1 Percut Sei Tuan are able to meet and balance the nutritional needs with their physical activities so that they do not experience malnutrition or excess nutrition. Therefore, food intake that is fulfilled and balanced with physical activity will make teenagers not easy to experience emaciation or obesity because changes in body fat mass can be prevented by doing physical activity.

This is in line with Sutrio's research (2017), based on the chi square analysis test it is found that there is a meaningful relationship of physical activity with nutritional status with a $\mathrm{p}$ value is 0.001 . Students whose physical activity is not strenuous tend to have sixty-five normal nutritional status $(53.7 \%)$. So it was concluded that students who have less strenuous physical activity have a greater percentage of normal nutritional status compared to students who have strenuous physical activity.

\section{Conclusion}

Based on the results of research and discussion about the relationship of physical activity with nutritional status in SMKN 1 Percut Sei Tuan Deli Serdang District, it can be concluded that there is a relationship of physical activity with nutritional status in students at SMK Negeri 1 Percut Sei Tuan with a $\mathrm{p}$ value of 0.003 smaller than 0.05 . Students who are doing physical activity have normal nutritional status because there is a balance between energy intake and expenditure.

\section{References}

Arisman. (2010). Gizi dalam Daur Kehidupan: Buku Ajar Ilmu Gizi Edisi 2. Jakarta: ECG Buku Kedokteran.

Afrilia, A,D., \& Festilia, S. (2018). Hubungan pola makan dan aktivitas fisik terhadap status gizi siswa SMP Al-Azhar Pontianak. Pontianak Nutrition Journal, 1(1): 10-13.

Brown, J, E., Isaacs, J., Krinke, B., Lechenberg, E., Ellen, \& Murtaugh, M, P. (2013). Nutrition through the life cycle. USA: Wadsworth.

Duma, G. (2013). Hubungan pola makan dan aktivitas fisik dan kejadian obesitas anak kelas V dan VI di Sekolah Dasar Yayasan Pendidikan Syafiyatul Amaliyah. Universitas Sumatera Utara.

Ermona, D, N., Wirjatmadi, B. (2017). Hubungan aktivitas fisik dan asupan gizi dengan status gizi lebih pada anak usia sekolah dasar di SDN Ketabang 1 Kota Surabaya Tahun 2017. 
Amerta Nutr, 97-105. doi: 10.2473/amnt.v2i1.2018.97-105.

Hidayati, N. (2017). Hubungan asupan energi, protein, lemak, karbohidrat dengan status gizi pada santriwati di Pondok Pesantren Darusalam Al-Faisholiyah Sampang Madura. (Tesis). Universitas Nahdlatul Ulama Surabaya, dari http://repository.unusa.ac.id/1740.

Kemenkes RI. 2013. Riset Kesehatan Dasar. Badan Penelitian dan Pengembangan Kesehatan. Kemenkes RI. Jakarta

Kemenkes RI. 2014. Pedoman Gizi Seimbang dan Angka Kecukupan Gizi. Kemenkes RI. Jakarta Kementerian Kesehatan Republik Indonesia. (2014). Pedoman Gizi Seimbang (Pedoman Teknis bagi Petugas dalam Memberikan Penyuluhan Gizi Seimbang). Jakarta: Direktorat Jenderal Bina Gizi dan KIA KKR.

Khasanah, D. (2016). Hubungan aktivitas fisik dengan status gizi remaja putri di Pondok Pesantren Ta'mirul Islam Surakarta. Fakultas Ilmu Kesehatan Universitas Muhammadiyah Surakarta.

Sukmaniah, S., Melisa, L.,Kevin, P., Karina, M., Fransisca, M \&Calvin K. (2013). Hubungan Antropometri, Aktivitas Fisik, dan Pengetahuan Gizi Dengan Asupan Energi Dan Komposisi Makronutrien Pada Remaja.

Wulandari, et al. (2020). The Implementation Analysis of Clinical Governance by the Medical Committee at Deli Serdang Hospital. Britain International of Humanities and Social Sciences, 2(1); 190-198.

Yaumil, F, MN. (2017). Hubungan antara aktivitas fisik dengan status nutrisi anak usia sekolah di SD BOPKRI Gondolayu Kota Yogyakarta. Ilmu Keperawatan STIKES Jenderal Achmad Yani Yogyakarta. 